\title{
GLL
}

00

\section{INFRASTRUCTURE INVESTMENT PROJECTS IN TERMS OF CONFORMITY WITH DOMAINS OF SUSTAINABLE DEVELOPMENT - A COMPARATIVE ANALYSIS OF MUNICIPALITIES IN THE VICINITY OF OLSZTYN CITY, IN WARMIA AND MAZURY REGION, POLAND}

\author{
Katarzyna Kocur-Bera
}

\begin{abstract}
Summary
The concept of sustainable development has a number of definitions. In a general sense, it assumes interdependence and equivalence of three domains of reality: environment, society and economy. Harmonisation of the relationship between the society, the economy and the natural environment requires the development of new, more efficient and environmentally-friendly technologies, limiting the exploitation of natural resources, energy consumption, the elimination of environment-polluting forms of production, as well as a widespread change of the way of life and revision of the acceptable hierarchy of values. According to the valid principles, the investment trends in municipalities should be in line with the domains of sustainable development, thereby providing balance in all the three areas of investment: environmental, economic and social. The aim of the study is to conduct a comparative analysis of the investment projects carried out in the period of 2007-2013 in selected municipalities of the Warmia and Mazury Region for their compliance with the principles of sustainable development of rural areas. Investment projects co-financed from EU funds were examined. This has allowed us to highlight the spheres of investment, which drew particular attention within the period of time under study. The shifted focus of investment efforts also testifies to backwardness in the supported sphere.
\end{abstract}

\section{Keywords}

infrastructural investment projects • sustainable development $\bullet$ EU funds

\section{Introduction}

The space around us is dynamic and it consists of a number of systems that interact with each other. Although each of these systems is autonomous to a certain extent, it also plays a role in supporting other systems and in the function of the whole. Sustainable development is defined as such that meets the current needs of people without limiting future generations' ability to satisfy their needs. The literature presents a number of concepts of sustainable development [Govindan 2013]. It is usually characterised 
by three domains: economic, social and environmental [Chaabane et al. 2010, Cieślak 2018]. They are interconnected, and all of them are extremely important in achieving the well being of individuals and whole societies. According to the 1987 definition by FAO, sustainable development "consists in such utilisation and conservation of natural resources and such orientation of technologies and institutions as to satisfy the needs of present and future generations". Creating a method for sustainable development of rural areas enables the use of appropriate technologies with simultaneous conservation of the natural environment (soil, water resources, plants, animals). Therefore, it is the development that ensures the achievement of the goals of environmental security as well as economic and social viability of agriculture. Implementation of concepts that meet the sustainable development principles encounters numerous obstacles of social, economic, intellectual and ethical nature. The 2030 Agenda for Sustainable Development assumes that the following should be done within the framework of implementation of the sustainable development assumptions: (1) eliminate poverty in all its forms; (2) eliminate famine, achieve food safety, better nutrition and promote sustainable agriculture; (3) ensure healthy life and promote well-being for people of all ages; (4) provide education of sufficient quality and promote lifetime learning opportunities; (5) achieve gender equality and reinforce the position of all women; (6) ensure accessibility of water and promote its sustainable management; (7) ensure access to cheap, reliable, sustainable and modern energy to everyone; (8) promote global and sustainable economic growth, full and productive employment and fair work to everyone; (9) build robust infrastructure, integration and permanence of industrialisation as well as support innovation; (10) reduce inequality within and between countries; (11) make towns and human settlements integral, safe and robust; (12) ensure sustainable patterns of consumption and production; (13) take urgent action in order to combat climate change and its effects; (14) save oceans and seas; (15) protect, restore and promote sustainable use of ecosystems, balance forest management, combat desertification, stop and reverse soil degradation and stop the loss of biodiversity; (16) promote peaceful and integrated society for sustainable development, ensure access to justice for all and build effective, responsible and comprehensive institutions on all levels; (17) reinforce measures for implementation of global partnership for sustainable development. A sustainable development concept should be introduced from the local level. A sustainable development strategy developed at a local level should strive to integrate environmental, economic and social elements. All of these elements should be treated equally [Kocur-Bera 2018]. Man is always the focus of sustainable development. $\mathrm{He}$ has the right to live a healthy and productive life in harmony with nature. Economic development has to go hand-in-hand with environmental protection. The intensity of the implementation of a strategy of sustainable development depends mainly on the technological status, organisation of social life, natural resources and biosphere capabilities. People around the world demand work, food, education, energy, healthcare, water and sanitary systems. Therefore, the whole community has to make efforts to prevent upsetting the social diversity and to provide all members with instruments allowing them to shape their future. 
Researchers have suggested a number of methods to study the sustainable development of areas, e.g. fuzzy set theory [Cornelissen et al. 2001], integrated assessment [Bond et al. 2001], ecological footprint [Ferng 2015], linear regression [Golusin et al. 2011], synthetic energy index [Garcia-Alvares et al. 2016], AHP method [Shen et al. 2015], multiple-criteria decision analysis [Jayarman et al. 2015], planetary boundaries concept [Cole et al. 2013] based on the Euclidean distance [Yang and Mei 2017], and many others. These methods are based on adopted indices that determine the measure of sustainable development, which enable a connection between man and the outside world. They provide valuable information [Bossel 1999], which guide later actions. According to Stevens [2005], sustainable development indices should determine: (a) the impact of business activity on the environment (e.g. consumption of resources, discharge of pollution, waste); (b) environmental services for the economy (e.g. natural resources, absorption function, contribution to the economic effectiveness and employment); (c) environmental services for the society (e.g. access to resources and conveniences, contribution to health, conditions of life and work); (d) effect of social variables on the environment (e.g. demographic changes, patterns of consumption, ecological education and information, institutional and legal framework); (e) impact of social variables on the economy (e.g. labour force, population, household structure, education and training; levels of consumption, institutional and legal framework); (f) impact of economic activity on the society (e.g. level of income, justice, employment). This study does not focus on particular sustainable development indices or their proper selection. Instead, we take into account the directions of investment in selected municipalities after Poland's accession to the EU, in 2007-2013. The analysis shows whether the investment projects carried out in these locations meet the principles of sustainable development, including sustainable investment. The study involved a survey in which the respondents indicated the weight of each completed investment supporting one (or all) of the domains of sustainable development. The principle of investment, in line with sustainable development, should take into account three equivalent spheres: economic, environmental and social. Such an approach enables finding a balance in satisfying individual economic and social needs while preserving the natural environment. Exploratory data were obtained from local sources of information owned by local governments (Barczewo and Dywity), road management boards, forest management boards and irrigation and drainage systems management boards. Owing to the selection of the study area, it was possible to make comparative analyses, which provided the basis for drawing conclusions concerning the direction of investments in the municipalities under study.

\section{Study methodology}

All investments subsidised from EU funds carried out in the municipalities under study were taken into account. The period of 2007-2013 was considered. The selection of the studied entities was determined by the similarity of location, a similar structure of land, and availability of programmes co-subsidised by the EU. Several dozen investment projects were completed during the period under study. Each investment project 
was qualified to a specific domain of sustainable development based on a survey. For this purpose, 50 experts were appointed, specialising in the area of sustainable development and socio-economic issues present in the municipalities, who assessed each investment project with respect to the direction of supported development. A survey helped to establish the weights for each task in regard to the spheres of sustainable development. For projects carried out over a period of several years, the investment outlay was divided into the years of the project execution, taking into account the weights that determine the direction of investment projects. In the final part of the study, disproportions between the supported directions of investment were assessed.

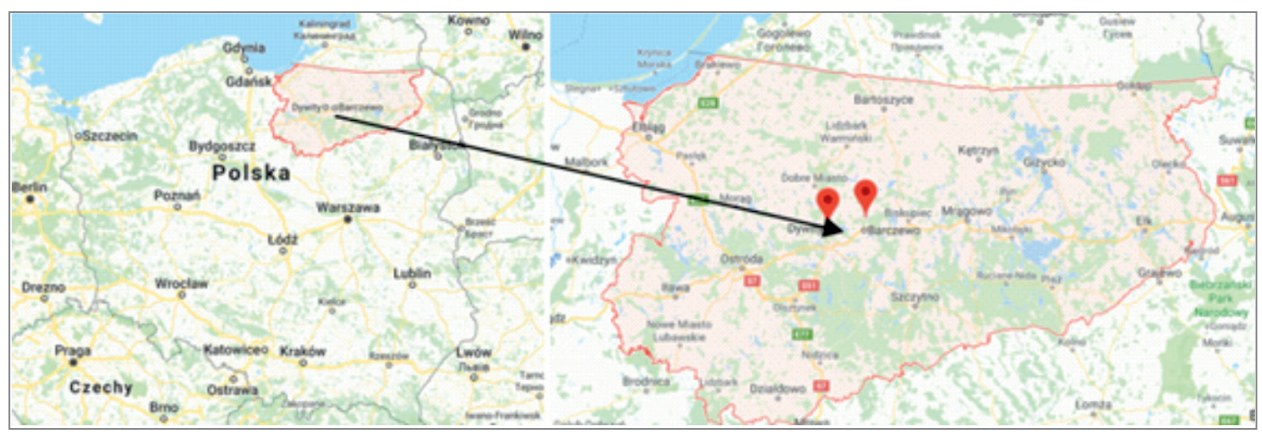

Source: author's own study based on www.google.pl/maps

Fig. 1. Study area

The analysed area covers two municipalities situated in the Warmia and Mazury Region, directly adjacent to the region capital - the city of Olsztyn. Figure 1 shows the location of the municipalities under study.

Both entities under study are equipped with technical infrastructure to a similar degree, and they also share a similar structure of land use. Table 1 lists the characteristic parameters describing both studied entities.

Table 1. The main data describing the study area

\begin{tabular}{|l|c|c|}
\hline \multicolumn{1}{|c|}{ Name } & Dywity & Barczewo \\
\hline Population & 10,642 & 17,190 \\
\hline Total area [ha] & 16,116 & 32,001 \\
\hline Population that uses the infrastructure & & \\
- water supply & $88.7 \%$ & $82.2 \%$ \\
- sewage removal & $53.1 \%$ & $49.3 \%$ \\
gas supply & $36.6 \%$ & $6.9 \%$ \\
\hline
\end{tabular}




\begin{tabular}{|c|c|c|}
\hline Structure of land use \\
\hline Forest and afforested land & $60 \%$ & $52 \%$ \\
\hline Land used for agriculture & $25 \%$ & $31 \%$ \\
\hline Other & $15 \%$ & $17 \%$ \\
\hline
\end{tabular}

Source: GUS [2019]

\section{Results and discussion}

Several dozen investment projects co-financed from EU funds were carried out in the selected entities over the period 2007-2013. All of the data were broken down by problem group and shown in Table 2. The task of each investment project was to reinforce one, two or three domains of sustainable development. To establish the extent to which each of the problem groups affect the analysed domain, a survey was conducted among a group of 50 experts. The survey results were used to calculate the impact weights of each of the assignments.

Table 2. Weights of problem groups of investment projects for sustainable development

\begin{tabular}{|c|l|c|c|c|}
\hline \multirow{2}{*}{ No. } & \multicolumn{1}{|c|}{ Problem group of investment projects } & \multicolumn{2}{c|}{ Weight for the domain in question } \\
\cline { 3 - 5 } & & \multicolumn{1}{|c|}{ social } & economic & environmental \\
\hline 1 & Water and sewage management & 0.30 & 0.35 & 0.35 \\
\hline 2 & $\begin{array}{l}\text { Modernisation/construction of roads/pavements/parking } \\
\text { lots }\end{array}$ & 0.40 & 0.48 & 0.12 \\
\hline 3 & Construction/repair of schools/sports facilities & 0.58 & 0.35 & 0.07 \\
\hline 4 & $\begin{array}{l}\text { Construction/repair of playgrounds/parks/leisure centres/ } \\
\text { outdoor fitness areas/public spaces }\end{array}$ & 0.59 & 0.35 & 0.06 \\
\hline 5 & Organising local integration events/festivities & 0.92 & 0.07 & 0.01 \\
\hline 6 & Training (activation) of the unemployed & 0.49 & 0.49 & 0.02 \\
\hline 7 & $\begin{array}{l}\text { Construction of selective waste collection sites/other } \\
\text { objects related to environmental protection }\end{array}$ & 0.06 & 0.07 & 0.87 \\
\hline
\end{tabular}

Source: author's own study

As the survey results have shown, the respondents claimed in one case that the problem groups of investment projects support the environmental domain. This concerns a project related to the construction of sites of selective waste collection. Additionally, water and sewage management is also an investment project improving the environmental values of space. In five problem groups, both the economic and social domain is supported. This concerns investment in transportation infrastructure, public util- 
ity buildings and facilities, and job activation of the unemployed. For one investment project, mainly the social domain is supported, and it concerns the organisation of local events aimed at building a sense of community. The survey results were used to calculate the weights for each investment project, which enabled dividing the investment outlays between three domains: social, economic, and environmental. Table 3 presents groups of investment tasks carried out in the municipalities under study over the analysed period of 2007-2013.

Table 3. Specification of investment outlays in the entities under study

\begin{tabular}{|c|l|c|c|c|c|}
\hline No. & \multicolumn{1}{|c|}{ Direction of investments } & $\begin{array}{c}\text { Municipality } \\
\text { of Dywity [PLN] }\end{array}$ & \% & $\begin{array}{c}\text { Municipality } \\
\text { of Barczewo [PLN] }\end{array}$ & $\%$ \\
\hline 1 & Water and sewage management & $2,400,000$ & 27.07 & 1.010 .000 & 2.69 \\
\hline 2 & $\begin{array}{l}\text { Modernisation/ construction of roads/ } \\
\text { pavements/ parking lots }\end{array}$ & 705,000 & 7.95 & 2.200 .000 & 5.86 \\
\hline 3 & $\begin{array}{l}\text { Construction/repair of educational/ } \\
\text { sports facilities/day-care rooms }\end{array}$ & 3815000 & 43.02 & 24.070 .000 & 64.07 \\
\hline 4 & $\begin{array}{l}\text { Construction/repair of playgrounds/ } \\
\text { parks/leisure centres/outdoor fitness } \\
\text { areas/public spaces }\end{array}$ & $1,331,000$ & 15.01 & 9.835 .000 & 26.18 \\
\hline 5 & $\begin{array}{l}\text { Organising local integration events/ } \\
\text { festivities }\end{array}$ & 231,000 & 2.61 & 40.000 & 0.11 \\
\hline 6 & $\begin{array}{l}\text { Training (activation) of the } \\
\text { unemployed }\end{array}$ & $8,867,000$ & 4.00 & 2185.57 & 0.55 \\
\hline 7 & $\begin{array}{l}\text { Construction of selective waste } \\
\text { collection sites/other objects related to } \\
\text { environmental protection }\end{array}$ & 30,000 & 0.34 & 210.000 \\
\hline
\end{tabular}

Source: author's own study

The municipalities under study engage in individual investment projects to a different extent (Table 3 ). The authorities of both municipalities under study regarded a range of projects of construction and repair of educational and sports facilities, schools and day-care facilities as the most important ones. These projects have consumed $43 \%$ of funds in the municipality of Dywity and as much as $64 \%$ in the municipality of Barczewo. The authorities of the municipality of Dywity also regarded waste and sewage management and construction/repair of leisure facilities for the community as worth investing in. In the case of the authorities of the municipality of Barczewo, this attitude concerns an investment project associated with leisure opportunities for the community. 
Table 4. Specification of investment outlays for individual domains (social, economic and environmental)

\begin{tabular}{|c|c|c|c|c|c|c|}
\hline \multirow{3}{*}{$\begin{array}{l}\text { No. of } \\
\text { task }\end{array}$} & \multicolumn{6}{|c|}{ Outlays for investment projects (taking into account their weights) } \\
\hline & \multicolumn{3}{|c|}{ Municipality of Dywity } & \multicolumn{3}{|c|}{ Municipality of Barczewo } \\
\hline & S & $\mathrm{E}$ & En & S & $\mathrm{E}$ & En \\
\hline 1 & 720,000 & 840,000 & 840,000 & 303,000 & 353,500 & 353,500 \\
\hline 2 & 282,000 & 338,400 & 84,600 & 880,000 & $1,056,000$ & 264,000 \\
\hline 3 & $2,212,700$ & $1,335,250$ & 267,050 & $13,960,600$ & $8,424,500$ & $1,684,900$ \\
\hline 4 & 785,290 & 465,850 & 79,860 & $5,802,650$ & $3,442,250$ & 590,100 \\
\hline 5 & 212,520 & 16,170 & 2,310 & 36,800 & 2,800 & 400 \\
\hline 6 & 173,950 & 173,950 & 7,100 & 100,450 & 100,450 & 4,100 \\
\hline 7 & 1,800 & 2,100 & 26,100 & 12,600 & 14,700 & 182,700 \\
\hline$\Sigma$ & $4,388,260$ & $3,171,720$ & $1,307,020$ & $21,096,100$ & $13,394,200$ & $3,079,700$ \\
\hline $\begin{array}{l}\text { Total per } \\
\text { person }\end{array}$ & 412,35 & 298,40 & 122,82 & 1227,23 & 779,19 & 179,16 \\
\hline$\Sigma$ & \multicolumn{3}{|c|}{$8,867,000$} & \multicolumn{3}{|c|}{$37,570,000$} \\
\hline
\end{tabular}

Source: author's own study

The analysis of data (listed in Table 4) shows that supporting the economic domain is equally important for both municipalities under study. $36 \%$ of funds in both municipalities under study are directed to development in this particular area. The municipality of Dywity engages $49 \%$ and the municipality of Barczewo - 56\% of investment outlays in the social domain. The least outlays in both municipalities are made in the environmental domain - 15\% in the municipality of Dywity and only $8 \%$ in the municipality of Barczewo.

Investment in sustainable development in municipalities should strive to preserve balance between the three domains (social, economic, and environmental). An analysis of Figure 2, which specifies the percentage of the financial outlays involved, taking into account their weights, indicates that none of the municipalities invest in an equivalent manner. The municipality of Dywity was the closest to the state of balance. The other municipality under study - Barczewo - showed huge disproportions, particularly in the aspect of the environmental domain, where outlays for environmental investments were nine times lower than for the social domain. 

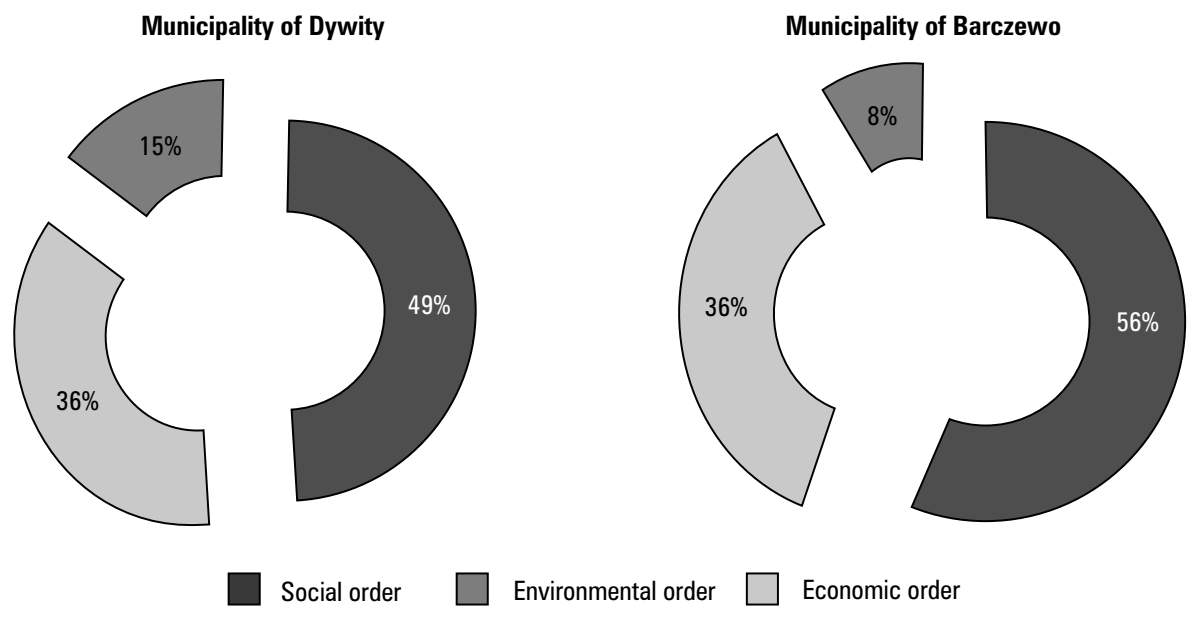

Source: author's own study

Fig. 2. Comparison of the direction of sustainable development financing in the entities under study

\section{Conclusion}

The idea of sustainable development is based on accounting for three dimensions: economic, environmental and social. Therefore, this development enables using technologies, which also ensure the achievement of the objectives of environmental safety, help to protect the environment as well as help to maintain the economic and social viability of space. Investment in measures supporting spatial development should be made while maintaining equivalence.

An analysis of the issue in the time period indicated shows that investments in various areas of sustainable development were made at various levels. Social development is the most popular because it directly affects human existence; investments in economic development or in the environment are less popular. This study is a pilot project on investing in sustainable development of areas. The directions of future research will focus mainly on extending the study area in terms of time and space.

This research was financed by the Ministry of Science and Higher Education, grant number 28.610.015-300.

\section{References}

Bond R., Curran J., Kirkpatrick C., Lee N., Francis P. 2001. Integrated impact assessment for sustainable development: A case study approach. World Dev., 29(6), 1011-1024.

Bossel H. 2001. Indicators for sustainable development: theory, method, applications. International Institute for Sustainable Development, Canada. 
Chaabane A., Ramudhin A., Paquet M. 2012. Design of sustainable supply chains under the emission trading scheme. Int. J. Prod. Econ., 135, 37-49.

Cieślak I. 2018. Wieloaspektowa analiza konfliktów przestrzennych. Wyd. UWM, Olsztyn.

Cole M.J., Bailey R.M., New M.G. 2014. Tracking Sustainable Development with a National Barometer for South Africa Using a Downscaled "Safe and Just Space” Framework. PNAS.

Cornelissen A.M.G., Van Den Berg J., Koops W.J., Grossman M., Udo H.M.J. 2001. Assessment of the contribution of sustainability indicators to sustainable development: A novel approach using fuzzy set theory. Agric. Ecosyst. Environ., 86, 173-185.

Ferng J. 2015. Nested open system: An important concept for applying ecological footprint analysis to sustainable development assessment. Ecol. Econ., 106, 105-111.

Garcia-Alvarez M.T., Moreno B., Soares I. 2016. Analyzing the sustainable energy development in the EU-15 by an aggregated synethetic index. Ecol. Indic., 60, 996-1007.

Golusin M., Muntilak Ivanovic O., Teodorovic N. 2011. The review of the achieved degree of sustainable development in South Eastern Europe - the use of linear regression method. Renew. Sustain. Energy Rev., 15(1), 766-772.

Govindan K., Kaliyan M., Kannan D., Haq A.N. 2014. Barriers analysis for green supply chain management implementation in Indian industries using analytic hierarchy process. International Journal of Production Economics, 147 (B), 555-568.

GUS 2019. Statistics Poland (GUS). https://stat.gov.pl/ (accessed: 29.03.2019).

Jayarman R., Colapinto C., La Tore D., Malik T. 2015. Multi-criteria model for sustainable development using goal programming applied to the United Arab Emirates. Energy Policy, 87, 447-454.

Kocur-Bera K. 2018. A comparative analysis of local investment projects implemented in Poland after its accession to the European Union to promote the sustainable development of rural areas. Transylvanian Review, XXVI (30), 7939-7949.

Shen L., Muduli K., Barve A. 2015. Developing a sustainable development framework in the context of mining industries: AHP Approach. Res. Policy, 46(1), 15-26.

Stevens C. 2005. Measuring Sustainable Development. Organization for Economic Cooperation and Development, OECD, Statistics Brief, 10, 1-8.

Yang Sh., Mei X. 2017. A sustainable agricultural development assessment method and a case study in China based on Euclidean distance theory. Journal of Cleaner Production, 168, 551-557.

Dr hab. inż. Katarzyna Kocur-Bera, prof. UWM

Uniwersytet Warmińsko-Mazurski w Olsztynie

Wydział Geodezji, Inżynierii Przestrzennej i Budownictwa

Instytut Geoinformacji i Kartografii

10-720 Olsztyn, ul. Prawocheńskiego 15

e-mail: katarzyna.kocur@uwm.edu.pl

ORCID: http://orcid.org/0000-0001-7056-5443 